\title{
Value-Chain Analysis of Fisheries Sector in Lake Nasser in Aswan
}

\section{Ahmed Mohamed Nasr-Allah, Olfat Anwar Habib and Malcolm William Dickson WorldFish, Abbassa, Abou Hammad, Sharkia, Egypt \\ Corresponding Author: Ahmed Nasr-Allah \\ Tel: +2010200 43126 \\ Email: ahmednassr@yahoo.com}

\section{Abstract}

Although, Lake Nasser fisheries is an important source of fish for residents of Aswan in Upper Egypt, limited information available about the value chain performance for those working in the chain. The current study aimed to improve understanding of fisheries value chain performance in Lake Nasser. Individual interviews and focus group discussions with fishers, traders, and processors used to collect quantitative and qualitative information about financial performance, employment creation and critical factors influencing performance of each node across the chain.

Tilapias account for $75 \%$, while pebbly fish (Alestes spp.) and tigerfish (Hydrocynus spp.) account for $13 \%$ of capture. Fish processing is an important subsector. Some fish species (mainly tigerfish and pebbly fish) are only consumed after going through a salting process. Fishers obtained a relatively low percentage $(49 \%)$ of the final consumer price. The average catch per fisher per day was $20 \mathrm{~kg}$ and the average total cost in the three fishing harbours was EGP 5210/t. One hundred tons of fish caught and sold provides an average 29.99 Full-Time equivalent jobs (FTE).

The current study suggests that the fishery is under pressure from overfishing. Critical factors facing the fisheries sector and influencing profitability are numerous. This value chain study improve our understanding of the performance of fisheries sector in Lake Nasser and identified limiting factors and action needed to support fisheries development in the Lake. 1

Keywords: Fisheries, Lake Nasser, value chain, tilapia, tigerfish, pebbly fish.

\section{Introduction}

Lake Nasser is an artificial lake established after the construction of the High Dam in Aswan in the 1960s to generate electricity and supply water for various uses throughout the year. The lake extends for more than 300 kilometers $(\mathrm{km})$ south of Egypt, with a shoreline of about $7000 \mathrm{~km}$ (Habib and Béné, 2008). It is the most important fishery source in Upper Egypt. The Lake providing an important source of income and livelihood for fishermen, fish traders and processors in Aswan Governorate and attracting large numbers of fishers from other governorates in Upper Egypt. The lake has become an important source of fish for the Egyptian consumers. The Lake has a diverse fishery with fifty-two fish species belonging to fifteen

\footnotetext{
${ }^{1}$ Acknowledgements

This study carried out as part of the Youth Employment in Aswan Governorate project implemented by CARE, Egypt and WorldFish, and was funded by the Swiss Agency for Development and Cooperation (SDC). The author is grateful Lydia Adeleke, Alaa El-Far and Walid Elsawy for their effort in review manuscript.
} 
families (van Zwieten et al., 2011). During recent decades, the Lake ecosystem changed and species diversity has declined (Béné et al., 2008; van Zwieten et al., 2011; Hall et al., 2015).

Tilapias, including Oreochomis niloticus, Sarotherodon galilaeus, Tilapia zillii (Coptodon zillii) and Oreochromis aureus comprise as much as $75 \%$ of the total catch by weight and are sold as fresh fish, while pebbly fish (Alestes spp.) and tigerfish (Hydrocynus spp.) are also important and are used as raw material to produce a traditional salted fish product (Nasr-Allah and Zakkar, 2018). Other fish species in the catch are Nile perch (Lates niloticus), squeaker catfish (Synodontis spp.), sharptooth catfish (Clarias gariepinus), Bagrus catfish (Bagrus spp.), and Nile carp (Labeo spp.). Fish catches from Lake Nasser by species group from year 2004 to year 2016 are presented in Figure 1 (GAFRD). The statistics indicate that catches trend decline radualy due to reduced tilapia catch. Tilapia cathe declined from 21.2 to 12.3 thousand ton during the same time. As the relative percentage of tilapia in catch declined from $85 \%$ to $67 \%$ over the time.

Value chain is a sequence of activities that add value to a product from its primary production, through to processing and marketing and final sale of the product to consumers (Kaplinsky and Morris, 2001; Macfadyen et al., 2011). Value chain analysis seeks to understand and describe the enterprises involved in the value-chain and their financial performance (Porter, 1985; Kaplinsky and Morris, 2001; Gereffi et al., 2005; Macfadyen et al., 2012; Anane-Taabeah et al., 2016). Value chain analysis (VCA) has become increasingly prominent as a form of analysis in the fisheries and aquaculture sectors (Veliu et al., 2009; Christensen et al., 2011; Macfadyen et al., 2011, 2012; Phiri et al., 2013; Nasr-Allah et al., 2014; Adeleke et al., 2015; AnaneTaabeah et al., 2016). Private sectors operators in the value chain and the government can improve value chain performance (Riisgard et al., 2010). The private business in the chain can improve performance through reducing costs, increasing output, and/or increasing the prices of their products (Macfadyen et al., 2011; Nasr-Allah et al., 2014). The ability of businesses in the value chain to source the inputs they need, to make or engage in their primary activity, or to sell and deliver products to customers, are impacted by policy, institutions and infrastructure developed by the government (Macfadyen et al., 2011, 2012; Nasr-Alla et al., 2012; El-Sayed et al., 2015).

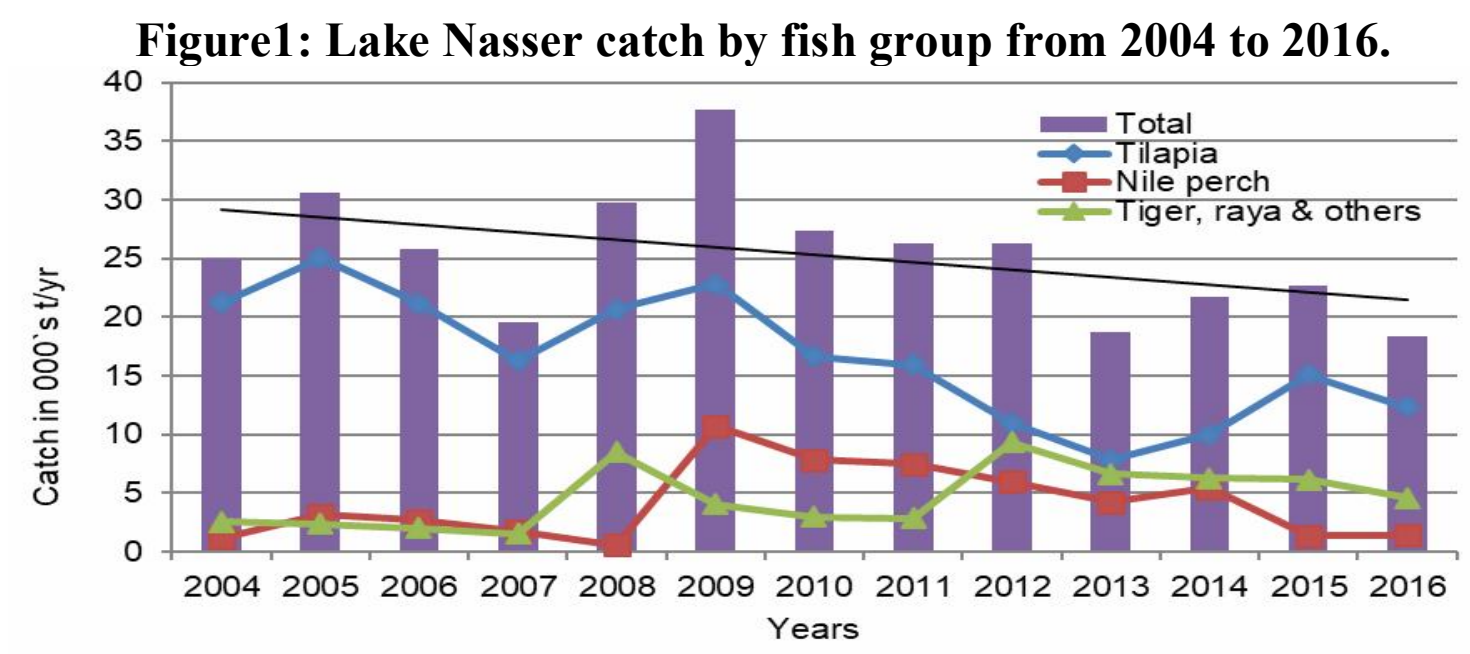

Source: GAFRD (2017). 
Adopting value chain analysis approach helps us to study the distribution of income for actors involved in the value-chain at each linkage and evaluate the relative importance of issues affecting competitiveness and the costs and earnings for actors involved in the value chain. Identify the weakness in value chain performance and suggest development strategies to improve performance of value chain actors (Macfadyen et al. 2012).

In spite of the existing of fishery in Lake Nasser for more than 50 years, the economic and financial performance of the fishermen and different actors across the value chain, have not been performed in value chain approach. Limited information available about level of inputs and outputs for every node in Lake Nasser fishery value chain. As well as, limited information documented about the sector limiting factors and suggested strategy to improve value chain performance in Lake Nasser fisheries.

The current study aims to map the fish catch value chain and the flow of fish products through the chain. In addition, it helps to identify the various actors, their functions, and existing linkages across the chain. The study aim as well to conduct a preliminary analysis of the input-output structure and the distribution of margins, return on investment and job creation along the chain. Finally aiming to identify the problems and opportunities facing different actors in the fisheries value chain.

\section{Materials and methods}

\subsection{Study area}

The current study focused on studying value chain analysis of fisheries in Lake Nasser, in Aswan, at the southern border of Egypt. There are three fishing harbors surrounding the Lake (Aswan, Garf Hussein and Abu Simbel) (Hall et al., 2015).

\subsection{Data collection}

Three main target groups identified in this study: fishers, traders (intermediaries, wholesalers, and retailers) and fish processors. Three questionnaires prepared for use in the study, one per each stage (fishers, processors and traders). The survey questionnaire tested and revised and simplifying wording for the interviewees, which conducted in 2016.

To ensure equal representation of the sample, fishers selected on a stratified random basis in the three fish landing sites (Aswan, Garf Hussein and Abu Simbel). Fishers were interviewed at their fishing camps in the lake and/or at the three landing harbors while they were landing their catch. As fish processors establishment are working in Aswan. The sample selected randomly from a list of fish processors working in the city. Interview of fish processors arranged at their business sites in Aswan. While, fish traders selected to represent different trading activities (intermediaries, wholesalers, and retailers). Interview of fish traders conducted in Aswan and Abu Simbel, where most of their activities were concentrated.

The number of interviewees for each category considered in this study are as follows; fishers 162; processors 22 (fresh and salted processors); and traders 23 (intermediaries, wholesalers and retailers). Two hundred and seven respondents (fishers 162, processors 22, and traders 23) interview conducted during the study. 
Data from the questionnaires entered into an Excel spreadsheet and checked for accuracy with the interviewers. The data collected allowed the estimation of a number of key indicators for each link in the value chain.

\subsection{Calculations}

The questionnaires generated data on capture volumes, sales price and sales values, and on operational and fixed costs, which allowed for the construction of costs and earnings models for each respondent across the chain. Operating costs for fishers are the costs that vary depending on the production/capture volume and include boat fuel, labor, transport, ice, food for fishers in the lake, and sales commission paid to intermediaries or wholesalers. For fish traders and processors, operating costs include fish bought, transportation, ice/salt, fuel, electricity, and wages.

Fixed costs are the costs that do not vary depending on production volumes. These typically include boat or equipment repair and maintenance, fishing gear and license fees. Annual depreciation $=($ Cost - Salvage Value $) /$ Useful life (Jolly and Clonts, 1993), where. Salvage value for all equipment calculated equal to zero as described by (Nasr-Alla et al., 2014).

The interviews included questions on the number of people employed and on the nature of that employment (full-time, part-time or seasonal). The data collected were converted into Full-Time Equivalent (FTE) jobs. FTEs estimated based on one FTE being the equivalent of 300 days per year in the fishing and processing sub-sectors, and 330 days FTE in the trading sub-sector as described by Macfadyen et al. (2012). Costs and earnings were calculated based on 2015 data collected in Egyptian Pounds (EGP) ( $\$ 1=$ EGP 7.73). The financial indicators calculated included: gross output values; operational profits (gross return-operational cost) per ton and as a percentage of sales; and net profits (gross return - (operational + fixed cost)). Total value-added calculated as (net profit + wages) per metric ton sold (Macfadyen et al., 2012). The percentage of total operational profits, net profits, and value-added made throughout the chain were also calculated.

\section{Results and Discussion}

\subsection{Lake Nasser fisheries value chain mapping}

The available information about Lake Nasser value chain shows the following: (a): Fishers

- Fishers; catch per day $20 \mathrm{~kg}$, sales EGP $6.3 / \mathrm{kg}$ and average fishing trip duration 2.5 days.

- Fishers obtain low percentage (49\%) of consumer price, due to the long supply chain.

- Tilapias represent $76 \%$ of catch and pebbly fish and tigerfish represent $13.6 \%$.

- Employment generation: 18.1 FTE per $100 \mathrm{t}$ of fish caught

(b) Fish trade

- Intermediaries; play an important role in collecting catches from fishers in their fishing camps and selling on to wholesalers at landing sites or in the market. 
- Intermediaries; sell $620 \mathrm{~kg} / \mathrm{day}$, at EGP $9.32 / \mathrm{kg}$ and average revenue 1.744 million EGP/yr.

- Employment generation:3.19 FTE per $100 \mathrm{t}$ sold

- Wholesaler; sell $1730 \mathrm{~kg} / \mathrm{day}$, at EGP 10.4/kg, Average sales value/year: EGP 5.4 million

- Employment generation: 1.63 FTE per 100 t sold

- Retailers; sell $104 \mathrm{~kg} / \mathrm{day}$, at EGP 12.79/kg and average sales value 438,573 EGP /year

- Employment generation: 7.08 FTE per 100 t sold

(b) Fish processing

- Fish processing; is an important subsector of the fisheries value chain in Aswan.

- Fresh fish processors; 98.4 t/year, hold fish on average for 4-5 days, average sales price: EGP 21/kg and average sales: EGP 1.77 million/year

- By volume, degutted fish $84 \%$, fillet $16 \%$ and product sold frozen.

- Fresh fish processing generate value added at average (EGP 3652/t)

- Processing of fresh fish generated 5.7 FTE per $100 \mathrm{t}$ of processed fish.

- Salted fish processors: 71 t/year, hold fish an average for 4-5 days, average sales price: EGP 13.7/kg and average sales: EGP 0.975 million/year

- By volume, Raya and tigerfish represent 93\%, product sold in salt in tins or jars

- Processing of salted fish processing generated 5.5 FTE/100 t processed.

- Salted fish processing generate value added at an average (EGP 2507/t).

\subsection{Operational and financial performance of fishing in Lake Nasser}

Findings of operational data for fishers at the three landing sites are displayed in Table 1. The data show that the highest average catch per fishing boat per year were in Abu Simbel and lowest in Aswan, while the sale price for captured fish was highest in Garf Hussein and lowest in Aswan. The overall employment rate was 18.1 FTE/100 t of fish catch ranging from 20.8 FTE/100 t in Aswan to 15.4 FTE/100 $t$ in Abu Simbel. The current study showed that fishing generates higher FTE compared to fish farming in Egypt. Macfadyen et al. (2011) reported that in the Egyptian aquaculture, fish farming generates $8.3 \mathrm{FTE} / 100 \mathrm{t}$ of fish production.

In all fishing areas, tilapia made up most of the catch $(76 \%)$. Catches of fish species for salting (pebbly fish and tigerfish) represented $13.5 \%$ of the total catch, while Nile perch and other species represented the remaining $10.6 \%$ of total catch. However, in Aswan a higher proportion of the total catch (57.6\%) was a small-sized tilapia $(<250 \mathrm{~g})$, compared to lower percentage in Garf Hussein and Abu Simbel (43.2\% and 42.7\% respectively). This suggests that higher pressure in Aswan may be responsible for lower catches and higher employment levels.

Revenue of fish sale per boat were higher in Garf Hussein and Abu Simbel harbor compared to Aswan (Table 2). This was due to higher catches and sales prices in both Garf Hussein and Abu Simbel compared with Aswan. Despite lower average operating costs, average income above operating costs per boat was lower in Aswan than in both Garf Hussein and Abu Simbel, following the same trend as sales revenue per boat. Return above operating cost per boat as a percentage of sales ranged from 


\section{Value-Chain Analysis of Fisheries Sector in Lake Nasser in Aswan}

$26 \%$ in Aswan to 44\% in Abu Simbel. While, fixed costs per boat were higher in Garf Hussein than Abu Simbel and lowest in Aswan. Income above total costs was similar in Garf Hussein and Abu Simbel, while Aswan recorded the lowest. Net profit as a percentage of sales was noticeably lower in Aswan (5\%) compared with the other two fishing ground (20-21\%), giving an average of $15 \%$. Value added calculated as revenue minus operational and fixed costs, excluding labor costs. Estimates of value added per ton were lowest in Aswan and highest in Garf Hussein, averaging EGP 3172/t. Macfadyen et al. (2012) reported lower value added by fish farmers (EGP 2989/t of fish sold) in Egypt.

Table 1: Operational data for the fishing activity in Lake Nasser in year 2015.

\begin{tabular}{|c|c|c|c|c|}
\hline Operational data & Aswan & Garf Hussein & Abu Simbel & Pooled \\
\hline Number interviewed & 55 & 51 & 56 & 162 \\
\hline Experience in fishing (yr) & $19 \pm 1.4$ & $29 \pm 1.8$ & $24 \pm 1.7$ & 24 \\
\hline Word duration in same location (yr) & $15 \pm 1.4$ & $17 \pm 1.7$ & $15 \pm 1.7$ & 16 \\
\hline Other source of income (\%) & 13 & 12 & 5 & 10 \\
\hline Yearly catch (kg/boat/yr) & $10,651 \pm 342$ & $12,995 \pm 410$ & $13,907 \pm 345$ & 12,506 \\
\hline Daily catch (kg/boat/day) & $36 \pm 1.1$ & $43 \pm 1.4$ & $46 \pm 1.1$ & 42 \\
\hline Average FTE/100 t & $20.8 \pm 0.8$ & $18.4 \pm 0.6$ & $15.1 \pm 0.5$ & 18.1 \\
\hline Sales price (EGP/kg; all species) & $5.4 \pm 0.2$ & $7.2 \pm 0.3$ & $6.2 \pm 0.2$ & 6.3 \\
\hline Catch distribution (\%) & & & & \\
\hline Tilapia - large & 17.6 & 11.3 & 22.1 & 17.3 \\
\hline Tilapia - medium & 5.6 & 9.5 & 17.8 & 11.6 \\
\hline Tilapia - small & 57.6 & 43.2 & 42.7 & 47.1 \\
\hline Nile perch - large & 3.0 & 4.6 & 1.4 & 2.9 \\
\hline Nile perch - small & 4.8 & 5.0 & 1.3 & 3.5 \\
\hline Pebbly fish & 5.8 & 7.0 & 9.7 & 7.7 \\
\hline Tigerfish & 2.5 & 11.4 & 3.2 & 5.8 \\
\hline Catfish (Squeaker \& Sharptooth) & 2.8 & 6.4 & 1.5 & 3.5 \\
\hline Bayad \& Others & 0.3 & 1.9 & 0.2 & 0.7 \\
\hline
\end{tabular}

* Tilapia size grades as reported by fishers: tilapia large, $\geq 1 \mathrm{~kg}$ average weight; tilapia medium, around $0.5 \mathrm{~kg}$ average weight; tilapia small, $\leq 250 \mathrm{~g}$ average weight.

Source: Computed survey data 2016.

Table 2: Summary of financial performance of fishers in Lake Nasser in year 2016.

\begin{tabular}{|c|c|c|c|c|}
\hline Financial performance data & Aswan & Garf Hussein & Abu Simbel & Pooled \\
\hline Fish sales (EGP/boat/yr) & $57,767 \pm 2,506$ & $92,720 \pm 3,366$ & $86,383 \pm 3,054$ & 78,621 \\
\hline Operational cost (EGP/boat/yr) & $40,293 \pm 1,512$ & $51,517 \pm 1,699$ & $47,895 \pm 2,025$ & 46,447 \\
\hline $\begin{array}{c}\text { Income above operational cost } \\
\text { (EGP/boat/yr) }\end{array}$ & $17,474 \pm 2,028$ & $41,444 \pm 3,048$ & $38,555 \pm 2,541$ & 32,273 \\
\hline Operational cost (EGP/t catch) & $3,912 \pm 154$ & $4,059 \pm 137$ & $3,466 \pm 131$ & 3,807 \\
\hline Operational profit (EGP/t) & $1,560 \pm 176$ & $3,253 \pm 259$ & $2,772 \pm 175$ & 2,511 \\
\hline Operational profit/sales (\%) & $26 \pm 2.9$ & $42 \pm 2.2$ & $44 \pm 2$ & 37 \\
\hline Labor cost (EGP/t) & $2,187 \pm 87$ & $2,206 \pm 73$ & $1,812 \pm 59$ & 2,065 \\
\hline Fixed cost per boat (EGP/yr) & $12,264 \pm 970$ & $20,977 \pm 1,581$ & $18,831 \pm 929$ & 17,269 \\
\hline Total cost per boat (EGP/yr) & $52,557 \pm 2,116$ & $72,493 \pm 2,678$ & $66,726 \pm 2,506$ & 63,717 \\
\hline $\begin{array}{c}\text { Income above total cost } \\
\text { (EGP/boat/yr) }\end{array}$ & $5,209 \pm 1,872$ & $20,468 \pm 2,859$ & $19,724 \pm 2,766$ & 15,004 \\
\hline Fixed cost per metric ton (EGP/t) & $1,158 \pm 86$ & $1,673 \pm 146$ & $1,398 \pm 87$ & 1,403 \\
\hline Total cost (EGP/t catch) & $5,071 \pm 154$ & $5,732 \pm 137$ & $4,865 \pm 131$ & 5,210 \\
\hline Net profit (EGP/t) & $401 \pm 168$ & $1,580 \pm 240$ & $1,374 \pm 202$ & 1,107 \\
\hline Net profit/sales (\%) & $5 \pm 3$ & $20 \pm 2.7$ & $21 \pm 2.7$ & 15 \\
\hline Value added per ton (EGP/t) & $2,588 \pm 144$ & $3,786 \pm 242$ & $3,186 \pm 184$ & 3,172 \\
\hline
\end{tabular}

Source: Computed survey data 2016. 


\subsection{Operational and financial performance of fish traders}

The fish trade subsector consists of three distinct functions or roles: intermediaries, wholesalers and retailers. Intermediaries are the group own or manage carrier boats and collect fish from fishers to deliver to wholesalers in the landing harbors. However, with liberation of fish trade in 2001, intermediaries started to use pickup trucks instead of carrier boats (Béné el al., 2009; Hall et al., 2015). Trucks are faster than carrier boats and can collect fish from fishers all around the lakeshore rather than the three landing sites. Use of cell phones allows the intermediaries to arrange lakeside meetings with fishers and enables transporting fish to wholesalers more quickly. This also means landing at locations where there is no system for recording catches or for collection of landing taxes. Wholesalers have land-based storage facilities and are able to sell fish in bulk outside Aswan (to other Upper Egypt governorates and El-Obour market in Cairo). They sell small quantities to retailers in Aswan according to retailer's market capacity.

The operational characteristics and financial performance results for the fish traders, wholesalers and retailers are displayed in Table 3. The highest volume of fish sales was for wholesalers (519 t/year) compared with intermediaries (187 t/year), and only $34 \mathrm{t} /$ year for retailers. Similarly, sales value per day for wholesalers was EGP 18,003, while for intermediaries it was EGP 5815 and for retailers EGP 1462. Tilapia sales prices indicated that wholesalers made around EGP $1 / \mathrm{kg}$ and retailers added more than EGP $2 / \mathrm{kg}$ to cover their expenses and generate income. The financial performance data for each type of trader indicated that they were all making good profits from their businesses.

Table 3. Operational and financial performance for fish trades in Lake Nasser.

\begin{tabular}{|c|c|c|c|c|}
\hline Parameters & Intermediaries & Wholesalers & Retailers & Pooled \\
\hline Sample size & 8 & 5 & 10 & 23 \\
\hline \multicolumn{5}{|l|}{ Operational data } \\
\hline Annual sales volume (t/yr) & $187 \pm 22$ & $519 \pm 121$ & $34 \pm 7$ & - \\
\hline Daily sales volume (t/day) & $0.62 \pm 0.07$ & $1.73 \pm 0.4$ & $0.104 \pm 0.02$ & - \\
\hline Average FTE/100 t of sales & $3.19 \pm 0.5$ & $1.63 \pm 0.4$ & $7.08 \pm 0.9$ & 4.5 \\
\hline Sales price (EGP/kg; all species) & $9.32 \pm 0.4$ & $10.40 \pm 0.6$ & $12.79 \pm 0.7$ & - \\
\hline Daily sales value (EGP/day) & $5,815 \pm 812$ & $18,003 \pm 3,838$ & $1,462 \pm 398$ & - \\
\hline \multicolumn{5}{|l|}{ Financial performance } \\
\hline Annual sales value (EGP/yr) & $\begin{array}{l}1,744,425 \\
\pm 243,647\end{array}$ & $\begin{array}{c}5,400,780 \\
\pm 1,151,466\end{array}$ & $\begin{array}{c}438,573 \\
\pm 119,393\end{array}$ & $1,971,523$ \\
\hline Operating costs (EGP/yr) & $\begin{array}{l}1,481,428 \\
\pm 189,029\end{array}$ & $\begin{array}{c}4,319,974 \\
\pm 1,055,661\end{array}$ & $\begin{array}{l}341,312 \\
\pm 97,380\end{array}$ & $1,602,800$ \\
\hline Operating profit (EGP/yr) & $\begin{array}{l}262,998 \\
\pm 71,242\end{array}$ & $\begin{array}{l}1,080,806 \\
\pm 151,294\end{array}$ & $\begin{array}{c}97,261 \\
\pm 22,982\end{array}$ & 368,723 \\
\hline Labor costs (EGP/t) & $494 \pm 71$ & $299 \pm 64$ & $622 \pm 178$ & 507 \\
\hline Operating profit (EGP/t) & $1,249 \pm 275$ & $2,340 \pm 364$ & $\begin{array}{l}2,873 \\
\pm 187\end{array}$ & 2,192 \\
\hline Operating profit/sales (\%) & $13 \pm 2.6$ & $22 \pm 2.8$ & $25 \pm 2.2$ & 20 \\
\hline Fixed costs (EGP/yr) & $\begin{array}{l}39,256 \\
\pm 5,966\end{array}$ & $\begin{array}{c}64,450 \\
\pm 17,292\end{array}$ & $\begin{array}{l}10,059 \\
\pm 1,951 \\
\end{array}$ & 32,038 \\
\hline Net profit (EGP/yr) & $\begin{array}{l}223,741 \\
\pm 74,822\end{array}$ & $\begin{array}{l}1,016,356 \\
\pm 136,887\end{array}$ & $\begin{array}{c}87,203 \\
\pm 21,711\end{array}$ & 336,684 \\
\hline Net profit per ton (EGP/t) & $1,009 \pm 314$ & $2,214 \pm 363$ & $2,565 \pm 191$ & 1,948 \\
\hline Net profit/sales (\%) & $11 \pm 3.1$ & $21 \pm 2.8$ & $22 \pm 2$ & 18 \\
\hline Total value added (EGP/t) & $1,503 \pm 254$ & $2,513 \pm 406$ & $3,187 \pm 235$ & 2,455 \\
\hline
\end{tabular}

Source: Computed survey data 2016. 


\section{Value-Chain Analysis of Fisheries Sector in Lake Nasser in Aswan}

The highest return on operating costs was for retailers, with an average of $25 \%$, followed by wholesalers $(22 \%)$, while intermediaries had the lowest return $(13 \%)$. Average net profits as a percentage of sales were similar for wholesalers and retailers, but lower for intermediaries. Similar result reported during studying value chain of Lake Malawi by Phiri et al. (2013), who reported that fish retailer generate slightly higher net profit.

The highest employment generation rate was in fish retailers $(7.08 \mathrm{FTE} / 100 \mathrm{t})$, followed by intermediaries (3.19 FTE/100 t) and wholesalers (1.63 FTE/100 t). Labor costs per metric ton were highest for retailers and lowest for wholesalers. While fixed costs were highest for wholesalers and lowest for retailers. The results indicate that the highest value added created per $100 \mathrm{t}$ fish sold was in the retailing, followed by wholesaling, and intermediaries (Table 4).

\subsection{Operational characteristics and financial performance of fish processing}

Operational information about fish processing in Lake Nasser is presented in Table 4 based on interviews with 14 salted fish processors and 8 fresh fish processors. The average years of experience were noticeably higher for salted fish processors (21.7) than fresh fish processors (9.9). Approximately one-third of the processors had other sources of income; for example, some owned fishing boats and collect salted fish from their boats or fishers for processing. The average sales volume per processor was higher for fresh fish compared with salted fish (98.4 and $70.9 \mathrm{t} /$ year, respectively). The average basket prices for all fish were also higher for fresh fish (EGP 20.9/kg) compared to salted fish (EGP 13.6/kg). Fresh fish processing focused mainly on tilapia ( $97 \%$ of quantity processed) compared to Nile perch $(1.5 \%)$. Tilapia degutted represent $(82 \%)$ while tilapia fillets represented $15 \%$ by volume of fresh fish processed. Salted fish processing focused mainly on different size grades of tigerfish (58\%) and pebbly fish (35\%).

Table 4. Operational characteristics of fish processing sub-sector in Lake Nasser.

\begin{tabular}{|l|c|c|c|}
\hline General information & Salted fish & Fresh fish & Pooled \\
\hline Number interviewed (sample size) & 14 & 8 & 22 \\
\hline Experience in fish processing (yr) & 21.7 & 9.9 & 17.4 \\
\hline Other income source (\%) & 35.7 & 25.0 & 32 \\
\hline Annual sales volume (t) & $70.94 \pm 11$ & $98.25 \pm 27$ & 81 \\
\hline Average FTE/100 t & $5.5 \pm 0.6$ & $5.7 \pm 1.6$ & 5.5 \\
\hline Sales price (EGP/kg; all species) & $13.6 \pm 0.7$ & $20.9 \pm 3.6$ & 16.3 \\
\hline Sales volume distribution bv species (\%) & \multicolumn{2}{|l|}{} \\
\hline Tilapia fillet (kg) & - & $95,316(97)$ & - \\
\hline Other fish (kg) & - & $2938(2.9)$ & - \\
\hline Tigerfish (kg) & $41,197(58.1)$ & - & - \\
\hline Pebbly fish (kg) & $25,071(35.3)$ & - & - \\
\hline Other species (kg) & $4,671(6.6)$ & - & - \\
\hline
\end{tabular}

Note: Numbers in parentheses refer to \% of total fish processed.

Source: Computed survey data 2016.

Salted fish (muluha) is a product that is unique to Lake Nasser and produced from tigerfish (Hydrocynus spp.), pebbly fish (Alestes spp.), Nile carp (Labeo spp.) 
and other species that are not marketed as fresh. The process of fish salting starting with gutting and salting the fish in plastic containers during which salt absorb the liquid from the fish. After around 3 week, the moisture content has dropped and it is a stable product for transporting from fishing camp to inland processors store. The processors repack the product into tins or jars for distribution and sale across Egypt (Nasr-Allah and Zakkar, 2018). Adeleke et al. (2015) reported that fishers in Ondo State in Nigeria practicing other form of processing such as precooking, drying and smoking. They also reported that $33 \%$ of fishers preserve fish through drying. The current study revealed that none of the fishers interviewed practice fish drying.

The financial performance of fish processors in this study are listed in Table 5. The average value of sales was higher for fresh fish processors than for salted due to higher sales volume and prices per kilogram. This also contributed to higher overall operating costs. Average operating profits for fresh fish processors were also higher, but when labor costs per metric ton were included, the average operating profit in term of percentage of sales was lower than for salted fish producers. The average net profit (percentage of sales) and net profit per metric ton were also lower for fresh fish producers due to the higher level of investment associated with these businesses (e.g. freezers and cold storage facilities). Akinola et al. (2006) reported that fish preservation using smoking and drying is common in Niger Delta. The authors attributed that to the less access to electricity by fisheries communities.

Table 5. Summary of financial performance of fish processing in Lake Nasser.

\begin{tabular}{|l|c|c|c|}
\hline Financial performance & Salted fish & Fresh fish & Pooled \\
\hline Annual sales value (EGP) & $975,046 \pm 164,388$ & $1,766,025 \pm 305,132$ & $1,262,677$ \\
\hline Operating costs (EGP) & $788,288 \pm 105,105$ & $1,526,789 \pm 264,343$ & $1,056,834$ \\
\hline Operating costs per year (EGP/t) & $11,112 \pm 634$ & $15,539 \pm 2,686$ & 13,820 \\
\hline Operating profit / ton sold (EGP/t) & $2,091 \pm 558$ & $3,028 \pm 1,054$ & 2,432 \\
\hline Operating profit/sales (\%) & $15 \pm 3$ & $12.9 \pm 2.6$ & 14 \\
\hline Fixed costs per metric ton & $151 \pm 24$ & $324 \pm 110$ & 214 \\
\hline Net profit (EGP/t) & $1,939 \pm 567$ & $2,703 \pm 1,058$ & 2,217 \\
\hline Net profit / sales (\%) & $13.8 \pm 3.1$ & $11.3 \pm 2.9$ & 13 \\
\hline Labor costs (EGP/t) & $567 \pm 71$ & $948 \pm 214$ & 706 \\
\hline Total value added (EGP/t) & $2,507 \pm 538$ & $3,652 \pm 1,036$ & 2,923 \\
\hline
\end{tabular}

Source: Computed survey data 2016.

\subsection{Value chain performance}

Changes in the average product price across the value chain are displayed in Table 6. This includes the average sales price for each link in the value chain. It is evident that prices increase at each node of the chain. This table also gives information on the percentage of final retail price achieved by each node in the value chain. The data indicates that fishers receive just below $50 \%$ of the final retail price. Phiri et al. (2016) reported that fishers in Lake Malawi receive only around $44.8 \%$ of consumer sales price, while Egyptian fish farmers receive $71 \%$ of the consumer price (Macfadyen et al., 2012). 
Table 6.Gross output values (average prices) for the Lake Nasser

fisheries value chain.

\begin{tabular}{|c|c|c|}
\hline Subsector & Average price EGP/kg & Retail prices (\%) \\
\hline Fishers & 6.29 & 49 \\
\hline Intermediaries & 9.32 & 73 \\
\hline Wholesalers & 10.40 & 81 \\
\hline Retailers & 12.79 & 100 \\
\hline
\end{tabular}

Source: Computed survey data 2016.

The operational and net profits and value added (per ton) at each link in the value chain are presented in Table 7 . The study results show that the retailing subsector generate the highest operational and net profits (EGP/t of fish sold). Fishers have the highest return on operation costs, followed by retailers. Net profit estimates showing that retailers and wholesalers generated the highest return on investment. Value added estimates indicated that retailers and fishers created $61 \%$ of the value added per ton. Wholesalers generated EGP 2513/t of value added, representing 24.2\% of value added generated per metric ton. The current study result shows noticeably high value added generation across the value chain compared to Egyptian aquaculture value chain (Macfadyen et al., 2012).

Table 7. Summary of financial performance of fishers and fish traders.

\begin{tabular}{|c|c|c|c|c|c|c|}
\hline & & Fishers & Intermediaries & Wholesalers & Retailers & Total \\
\hline \multirow{3}{*}{$\begin{array}{c}\text { Operation } \\
\text { profit }\end{array}$} & EGP/t & 2511 & 1249 & 2340 & 2873 & 8972 \\
\hline & $\%$ & 37.3 & 13.4 & 21.7 & 24.9 & \\
\hline & $\%$ of total & 28 & 14 & 26 & 32 & 100 \\
\hline \multirow{3}{*}{ Net profit } & EGP/t & 1107 & 1009 & 2214 & 2565 & 6896 \\
\hline & $\%$ & 15.2 & 10.8 & 20.5 & 22.2 & \\
\hline & $\%$ of total & 16 & 15 & 32 & 37 & 100 \\
\hline \multirow{3}{*}{$\begin{array}{c}\text { Total } \\
\text { value } \\
\text { added }\end{array}$} & EGP/t & 3172 & 1503 & 2513 & 3187 & 10375 \\
\hline & $\%$ & 31 & 14 & 24 & 31 & \\
\hline & $\%$ of total & 30.6 & 14.5 & 24.2 & 30.7 & 100 \\
\hline
\end{tabular}

Source: Computed survey data 2016.

Fish processing is an important activity in Lake Nasser fisheries value chain. A summary of benefits generated by the fish processing displayed in Table 8 . Fresh fish processing generated slightly higher FTE/100 t compared to salted fish processing. Both labor costs and output value per ton were higher for fresh fish processing. Similarly, operational and net profits were higher in fresh fish processing. However, these data show that fresh fish processing generates higher value added (EGP 3652/t) compared to fish salting processing (EGP 2507/t) due to the high cost of labor in fresh fish processing. Similar conclusion reported by, Anihouvi et al., (2012) and Nasr-Allah and Zakkar (2018), who stated that salted fish is low cost methods of fish preservation. 
Table 8. Summary of fish processing performance.

\begin{tabular}{|c|c|c|c|}
\hline Parameters & Salted fish & Fresh fish & Pooled \\
\hline FTE/100 t & 5.5 & 5.7 & 5.6 \\
\hline Output value or basket price (EGP/t) & 13,597 & 20,898 & 16,252 \\
\hline Labor cost (EGP/t) & 567 & 948 & 706 \\
\hline Operational profit (EGP/t) & 2,091 & 3,027 & 2,431 \\
\hline Net profit (EGP/t) & 1,939 & 2,703 & 2,217 \\
\hline Value added (EGP/t) & 2,507 & 3,652 & 2,923 \\
\hline
\end{tabular}

Source: Computed survey data 2016.

\subsection{Job creation in Lake Nasser fishery value chain}

The current study found that the fishing subsector resulted in total employment of 30 jobs (FTE) per $100 \mathrm{t}$ of fish caught in Lake Nasser. The highest employment level was in fishing (18.1 FTE/100 t of catch, or $60 \%$ of total FTE created) followed by retailing (24\% of FTE), and intermediaries (11\% of FTE) and wholesaling at (5\% of FTE) (Table 10). More than $90 \%$ of fishers working in Lake Nasser are from Upper Egypt governorates (Fayoum, Sohag and Qena). Meanwhile, 50\% of wholesalers and $65 \%$ of retailers are also from outside Aswan (Table 9). This indicates that the fisheries sector is an important source of job creation not just for Aswan resident, but also for other governorates, including those of Upper Egypt. The current study found that most work was full time (>79\%) indicating that fish businesses generate a good level of income across all subsectors. Furthermore, in fish retailing and wholesaling, almost all employment was full time (97\% and $95 \%$ respectively). Youth ( $\leq 30$ year age) represented $49-59 \%$ of total FTE indicating that working in the fisheries value chain is an acceptable option for young men. Due to the remoteness of fishing grounds from harbors and poor living conditions in fishing camps, all fishers interviewed were men.

Job creation in fish processing is limited, as only a limited percentage of catches (15\%) undergoes processing. Fish processing generates on average 5.5 FTE/100 t of fish processed. The official fish catch statistics from Lake Nasser is between years 2004 and 2013 is 26,704 t/year. Estimating employment across the value chain based on the average catch indicate that the Lake Nasser fisheries and related businesses generate 8227 FTE, with 4833 FTE engaged directly in fishing. However, it is very likely that GAFRD statistics underestimated because of underreporting of catches to avoid fish landing taxes, which also casts doubt on the total employment estimation (Halls et al., 2015). Lower contribution to FTE generation in aquaculture value chain and fish seed value-chain in Egypt reported by Macfadyen et al, (2012) and NasrAllah et al, (2014). 
Table 9. Employment generation in the Lake Nasser fisheries value chain.

\begin{tabular}{|c|c|c|c|c|c|c|}
\hline \multirow[b]{2}{*}{ Employment } & \multirow{2}{*}{$\begin{array}{c}\text { Jobs } \\
\text { (FTE)/100 } \\
\text { t sold }\end{array}$} & \multirow{2}{*}{$\begin{array}{l}\text { Percentage } \\
\text { across the } \\
\text { value chain }\end{array}$} & \multirow{2}{*}{$\begin{array}{c}\text { Full-time } \\
\text { jobs }(\% \text { of } \\
\text { FTE) }\end{array}$} & \multirow{2}{*}{$\begin{array}{c}\text { Youth }(\% \\
\text { less than } 30 \\
\text { years old })\end{array}$} & \multicolumn{2}{|c|}{ Source of labor } \\
\hline & & & & & Aswan & $\begin{array}{c}\text { Other } \\
\text { governorates }\end{array}$ \\
\hline Fishers & 18.1 & $60 \%$ & $79 \%$ & $57 \%$ & $9 \%$ & $91 \%$ \\
\hline Intermediaries & 3.19 & $11 \%$ & $78 \%$ & $53 \%$ & $47 \%$ & $53 \%$ \\
\hline Wholesalers & 1.63 & $5 \%$ & $95 \%$ & $59 \%$ & $50 \%$ & $50 \%$ \\
\hline Fish retailers & 7.08 & $24 \%$ & $97 \%$ & $49 \%$ & $35 \%$ & $65 \%$ \\
\hline TOTAL & 29.99 & $100 \%$ & & & & \\
\hline
\end{tabular}

\section{Source: Computed survey data 2016.}

\subsection{Analysis of critical factors limiting fisheries development}

Focus group discussions (FGD) were held with board members of fishers' associations and resulted in identification of a series of challenges and potential solutions as follows

- Livelihood challenges (affording fuel and bread required during fishing trip, poor living condition in the lake, lack of health service and no maintenance of navigation lighting system in the Lake).

- Inputs availability challenges (access to credit; lack of skilled labor, poor ice quality).

- Operation challenges include (poor security in around Lake and overfishing problem).

- Post-harvest and marketing challenges include (poor post handling and no fish auction).

\subsection{Recommended action for improving value chain performance}

Suggested recommendations for improving value chain performance in this study mainly based on the critical issues identified during the FGD and issues raised by fishers during interviewing.

- Establish new service organizations to provide inputs (such as nets, handling boxes and fish-salting equipment) and help with fish marketing. Also, facilitate getting operations inputs such as food, fuel and ice. .

- Develop community-based fisheries management plan to create an awareness among stakeholders about the current situation in the Lake. The plan should emphasis on the importance of implement best fisheries management practice for sustainability of catch.

- Improve living condition within the fishing camps in the lake. Renovate health care service boats providing basic services for fishers in the Lake.

- Train fishers on deliver first aid to victims until they can reach medical centers to get the appropriate treatment and medical care. 
- Establish social and health insurance scheme for fishers as they work in a vulnerable situation.

- Train fishers on the importance of good fish handling practices in maintaining quality, reduce spoilage, extend shelf life in markets and obtain higher selling prices.

- Establish of fish auctions in both Aswan and Abu Simbel to for higher selling price improve fishermen income.

- Provide training on processing of both fresh and salted fish and the conversion of fish processing waste into fishmeal should be promoted to increase processors income.

\section{Conclusion}

Nasser Lake fishery is an important source of food and job creation in Aswan and Upper Egypt. This current study has demonstrated that the sector generates considerable levels of economic activity, profits and employment. Most of people working in the sector for long time, indicating the sustainable nature of the valuechain and the lack of alternative livelihood opportunities. Fish value chain in the lake contributes significantly to direct job creation, including for youth. No women identified employed in the fishers or fish processing sectors in Aswan. The sector now facing a number of significant challenges. Official statistics of fish catch shows declining trend in the last years mainly due to reduced tilapia catches. The opportunities for improving in value-chain performance, provides a strong argument for action to be done by private-sector actors to maintain employment benefits generated in the sector, and to increase such benefits in the future.

Value chain analysis is a useful tool for understanding the financial benefits that generated by the fisheries sector and identifying the critical factors that affect the financial and social performance of the value chain. Understanding these critical factors can be used to recommend actions for better financial and social benefits created by the sector. The study recommends some of the necessary actions to ameliorate this sector will be the responsibility of the sector itself, government, donors and non-governmental organizations.

\section{References}

Adeleke, M. L., Omogbemi, T. E., Ogunjobi V. O., 2015. Value chain strategies in fish production for food security in Nigeria: The case of selected key actors in fish production in Ondo State Coastal Areas. Int. J. of Inn. Res. \& Dev., 4(13): 170173.

Ahmed, S. 2009. The economics of fish production and marketing in the White Nile state-Sudan (Doctoral dissertation, M. Sc. thesis, Faculty of Agriculture, University of Khartoum, 68). 
Akinola, O.A.; A.A. Akinyemi and B.O. Bolaji, 2006. Evaluation of traditional and solar fish drying systems towards enhancing fish storage and preservation in Nigeria. J. Fish. Int., Pakistan 1(3-4): 44-9.

Anane-Taabeah, G., Quagrainie, W., Amisah, S., 2016. Assessment of farmed tilapia value chain in Ghana. Aquacult. Int., 24(4), 903-919.

Anihouvi, V.B.; J.M. Kindossi and J.D. Hounhouigan, 2012. Processing and quality characteristics of some major fermented fish products from Africa: a critical review. Int Res J. Biol Sci., 1(7): 72-84.

Béné, C.; Bandi, B., Durville, F., 2008. Liberalization reform, 'neo $\square$ centralism' and black market: The political diseconomy of Lake Nasser fishery development. Water Alternatives, 1(2): 219】 235.

Béné C, Abban, E.K., Abdel-Rahman, S.H., Ayyappan, S., Brummett, R., Dankwa, H.R., Das, A.K., Habib, O.A., Katiha, P.K., Kolding, J., 2009. Improved fisheries productivity and management in tropical reservoirs. CPWF Project Number 34. CGIAR Challenge Program on Water and Food Project Report series. Retrieved from: https://cgspace.cgiar.org/bitstream/handle/10568/3923/?sequence $=1$

Christensen, V., Steenbeek, J., Failler, P., 2011. A Combined Ecosystem and Value Chain Modeling Approach for Evaluating Societal Cost and Benefit of Fishing. Eco. Mod., 222(3):857-864.

El-Sayed, A., Dickson, M., El-Naggar, G., 2015. Value chain analysis of the aquaculture feed sector in Egypt. Aqua., 147 (2015): 92-101.

[GAFRD] General Authority for Fishery Resources Development, 2015. Fish Statistics Yearbook for 2013. Ministry of Agriculture and Land Reclamation, Egypt.

Gereffi, G., Humphrey, J., Sturgeon, T., 2005. The governance of global value chains. Rev. of Int. Polit. Econ., 12 (1), 78-104.

Habib, O.A. and Béné C. 2008. Insights into the political dis-economy of Lake Nasser fishery development. IIFET 2008 Conference, July 22-25, Nha Trang, Vietnam.

Halls, A.S., 2015. Lake Nasser fisheries: Recommendations for management, including monitoring and stock assessment. Penang, Malaysia: WorldFish. Program Report: 2015-40.

Halls, A.S., Habib, O.A., Nasr-Allah, A., Dickson, M., 2015. Lake Nasser fisheries: Literature review and situation analysis. Penang, Malaysia: WorldFish. Program Report: 2015-42.

Jolly, C.M., Clonts, H.A., 1993. Economics of Aquaculture. Food Products Press, New York.

Kaplinsky, R., Morris, M., 2001. A Handbook for Value Chain Research. Brighton: University of Sussex, Institute for Development Studies.

Macfadyen, G., Nasr Allah, A., Kenawy, D., Mohamed, F., Hebicha, H., Diab, A., Hussein, S., Abouzied, R., El-Naggar, G., 2011. Value-chain analysis of Egyptian aquaculture. Penang, Malaysia: WorldFish. Project Report: 2011-54. 
Macfadyen, G., Nasr Allah, A., Kenawy, D., Mohamed, F., Hebicha, H., Diab, A., Hussein, S., Abouzied, R. \& El-Naggar, G., 2012. Value-Chain Analysis - an assessment methodology to estimate Egyptian aquaculture sector performance, and to identify critical issues and actions for improvements in sector performance. Aquaculture, 362-363: 18-27.

Nasr-Alla, A., Macfadyen, G., Dickson, M., Al-Kenawy, D., Fathi, M., and ElNaggar, G., 2012. Value chain analysis of the Egyptian aquaculture sector. Proceedings of IIFET Conference in Tanzania from 16 to 20 July 2012. Dar El Salam, Tanzania.

Nasr-Allah, A., Dickson, M., Al-Kenawy, D., El-Naggar, G., Ahmed, M., Azazy, G., Garana, Y., Diab, A., 2014. Value Chain Analysis of Egyptian Fish Seed Production. Egyptian J. of Aqua., Special issue for the $4^{\text {th }}$ Conference of Central Laboratory for Aquaculture Research, (2014): 351-372.

Nasr-Allah, A.M. and Zakkar, A. 2018. Comparison of technical and economic performance of fresh and salted fish processors in Lake Nasser. Abbassa Inter. J. for Aqua., Vol. 11(1): 109-129. www.abbassajournal.com/

Phiri, L.Y., Dzanja, J., Kakota, T., Hara, M., 2013. Value chain analysis of Lake Malawi fish: A case study of Oreochromis spp (Chambo). Int. J. of Bus. and Soc. Sci., 4(2): 170-181.

Porter, M., 1985. Competitive Advantage: Creating and Sustaining Superior Performance. New York: The Free Press.

Riisgard, L., Bolwig, S., Ponte, S., Du Toit, A., Halberg, N., Matose, F., 2010. Integrating poverty and environmental concerns into value-chain analysis: a strategic framework and practical guide. Dev. Pol. Rev., 28 (2), 195-216.

van Zwieten, P.A.M., Béné, C., Kolding, J., Brummett, R., Valbo-Jørgensen, J., 2011.

Review of tropical reservoirs and their fisheries - The cases of Lake Nasser, Lake Volta and Indo-Gangetic Basin reservoirs. FAO Fisheries and Aquaculture Technical Paper No. 557. Rome: FAO. 2011. 148 pp.

Veliu, A., Gessese, N., Ragasa, C., Okali, C., 2009. Gender Analysis of Aquaculture Value Chain in Northeast Vietnam and Nigeria. Agriculture and Rural Development. The World Bank Discussion Paper 44. Washington, DC.

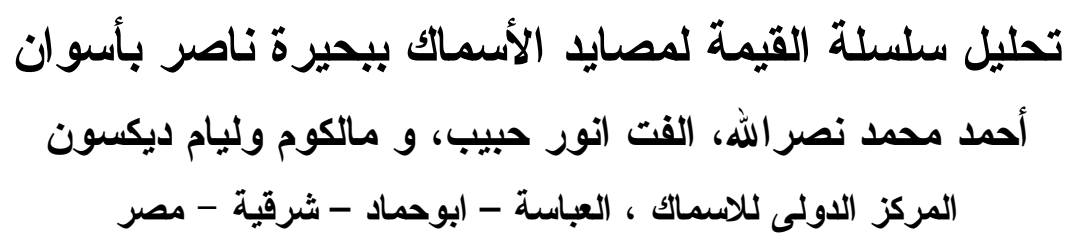

الملخص العربي

على الرغم من أن بحيرة ناصر تمثل اهمية كبيرة لتوفير الاسماك وفرص العمل و الدخل لهحافظة

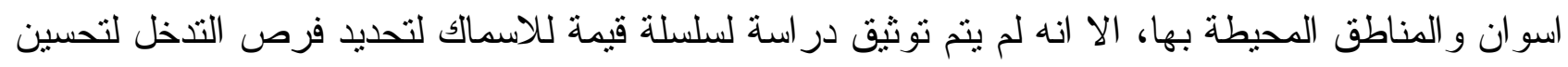
الاداء فى هذا النشاط. تهدف الدراسة الحالية الى التعرف على اداء سلسلة القيمة لدصايد الاسماك بيحيرة 


\section{Value-Chain Analysis of Fisheries Sector in Lake Nasser in Aswan 1 r r}

ناصر • و اعتمدت الدر اسة على بيانات دراسة حقلية تم تجميعها من خلال استمار ات استبيان وحلقات نقاشية

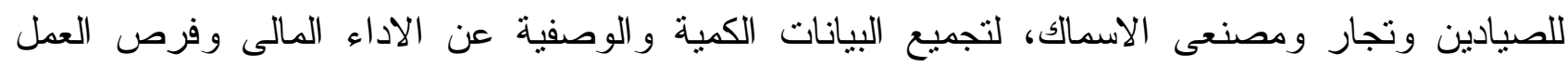
ومحددات القطاع فى كل مرحلة خلال سلسلة القيمة.

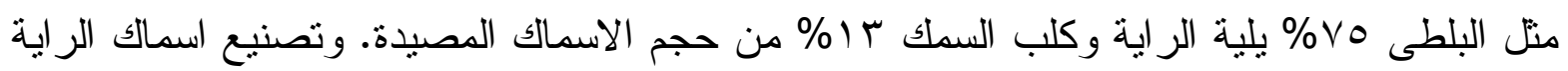

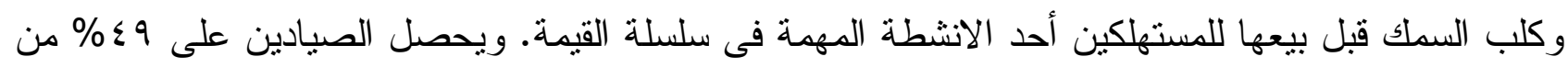

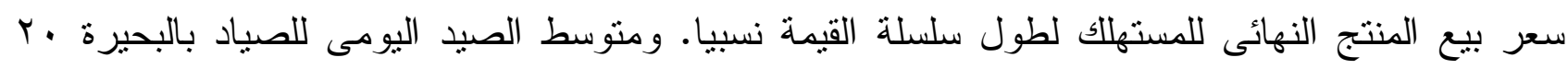

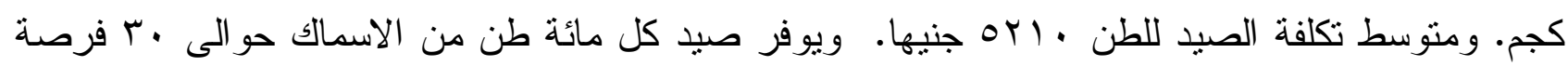
عمل مستديمة.

اظهرت الدر اسة الحالية ان البحيرة تتعرض للصيد الجائر لصغر حجم الاسماك المصيدة. ومعوقات

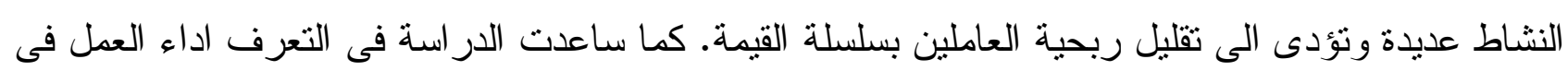

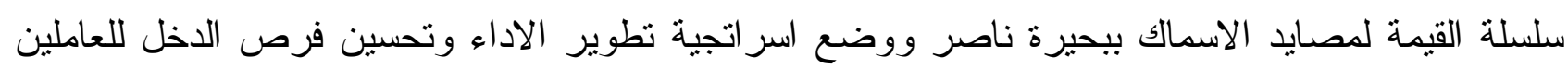
فى مر احل سلسلة القيمة المختلفة. وتوصى الدراسة العاملين بالنشاط بالعمل مع الجهات المسئولة عن البحيرة للحد من الصيد الجائر.

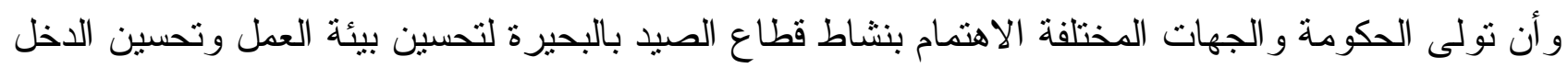
و واستدامة النشاط للعاملين بمر احل سلسلة القيمة المختلفة. 